PRÁVNE ROZPRAVY ON-SCREEN III. - Sekcia verejného práva

online vedecká konferencia - 7. máj 2021

\title{
DIEŤA AKO OBEŤ DROGOVEJ KRIMINALITY
}

\section{CHILD AS A VICTIM OF A DRUG CRIME}

Silvia Ondrejková ${ }^{1}$

https://doi.org/10.24040/pros.07.05.2021.svp.212-229

\begin{abstract}
Abstrakt
Článok vychádza z aktuálnych teoretických a praktických poznatkov o drogovej kriminalite. Predmetom skúmania je charakterizovanie pojmov drogy, drogová kriminalita a diet’a ako obet' drogovej kriminality. Ciel’om článku je prostredníctvom vybraných súdnych rozhodnutí poukázat' na detské obete drogovej kriminality na území Slovenskej republiky. V článku boli použité štandardné metódy využivané v odboroch sociálnych vied či spoločenských vied, a to analýza, komparácia, syntéza a štatistika.
\end{abstract}

\section{Kl'účové slová}

Diet’a, drogy, drogová kriminalita.

\begin{abstract}
The article is based on current theoretical and practical knowledge about drug crime. The subject of the research is the characterisation of drugs, drug crime and child as a victim of drug crime. The aim of the article is to point out, through selected court decisions, to child victims of drug crime in the Slovak Republic. The article used standard methods for writing in social sciencies, namely analysis, comparison, synthesis and statistics.
\end{abstract}

\section{Key words}

Child, drugs, drug crime.

\section{Drogy}

Na to, aby sme mohli sme mohli priblížit problematiku detských obetí drog, je potrebné hned' v úvode ozrejmit' a vysvetlit' základné pojmy, ktoré sa danej témy týkajú. Najväčšou hrozbu drogovej kriminality vôbec je dopad na život a zdravie užívatel'ov drog. Pre pojem droga existuje množstvo definícií vo viacerých vedeckých odvetviach, preto nie je možné zabezpečit', aby význam tohto pojmu ostal nemenný a platil neustále. Väčšina z definícií však vychádza práve z definície Svetovej zdravotníckej organizácie, ktorá je vo všeobecnosti vnímaná ako ustálená a drogu vymedzuje ako ,látku (substanciu), ktorá ak je vpravená do

\footnotetext{
${ }^{1}$ Mgr. Silvia Ondrejková, Univerzita Mateja Bela v Banskej Bystrici, Právnická fakulta, interná doktorandka Katedra trestného práva, kriminológie, kriminalistiky a forenzných disciplín, silvia.ondrejkova@umb.sk
} 


\section{PRÁVNE ROZPRAVY ON-SCREEN III. - Sekcia verejného práva}

online vedecká konferencia - 7. máj 2021

organizmu, môže pozmenit' jednu alebo viac jeho funkcií, pôsobí priamo alebo nepriamo na centrálnu nervovú sústavu a môže mat' priznané postavenie lieku. “2 Definíciu pojmu droga však v Trestnom zákone nenájdeme. Jediným ustanovením, v ktorom sa nachádza tento pojem je $\S$ 135 - Prechovávanie drog pre vlastnú potrebu. Pojem droga sa však nachádza iba v názve ustanovenia, v samotnom jeho obsahu už nie. Z obsahu je však možné vyvodit', že na účely trestného práva sa drogou rozumie omamná látka, psychotropná látka, jed a prekurzor. Nasledovné pojmy bližšie definuje zákon č. 139/1998 Z.z. o omamných látkach, psychotropných látkach a prípravkoch v znení neskorších predpisov. Omamnými látkami sa na účely tohto zákona rozumejú látky spôsobilé nepriaznivo ovplyvnit’ psychiku človeka, jeho rozpoznávacie alebo ovládacie schopnosti a sociálne správanie. Ide o látky vyvolávajúce návyk a fyzickú závislost' charakterizovanú zmenami správania sa so závažnými zdravotnými a psychosociálnymi následkami. Takýmito látkami sú napríklad ópium, kokaín alebo heroín. Psychotropnými látkami sú látky ovplyvňujúce stav l'udskej psychiky tým, že pôsobia na centrálnu nervovú sústavu, avšak s menej závažnými psychosociálnymi následkami a následkami na zdraví. Príkladom psychotropnej látky je napríklad amfetamín. Jedom je látka, ktorá už v malých množstvách spôsobuje poškodenie biologických funkcií až smrt' organizmu. Jed, ktorý má špecifické účinky sa nazýva toxín ${ }^{3}$ a prekurzorom sa rozumie chemická látka, ktorá slúži na výrobu omamnej alebo psychotropnej látky, alebo pri ich výrobe. Ide napríklad o efedrín, ktorý sa využíva pri výrobe metamfetamínu. Prekurzor je obvykle základom na tvorbu syntetických drog. Iné prekurzory sa používajú aj ako katalyzátory alebo rozpúšt’adlá a niektoré sa využívajú aj v procese spracovávania prírodných drog. ${ }^{4}$ Návykovými látkami sú všetky látky schopné nepriaznivo ovplyvnit’ psychiku človeka, jeho sociálne správanie a ovládacie alebo rozpoznávacie schopnosti. ${ }^{5} \mathrm{~S}$ uvedenými pojmami sa spájajú aj dôsledky, ktoré vyvolávajú. Ide predovšetkým o návyk, ktorý Svetová zdravotnícka organizácia definuje ako stav, v ktorom užívatel' nemá nutkavú potreby užit’ drogu, ale silnú túžbu po nej. Závislost’ od drogy je psychologická a nie fyziologická. Predpoklad na zvyšovanie dávky u konzumenta

\footnotetext{
2 ČENTÉŠ, J.: Hmotnoprávne aspekty trestnej činnosti páchanej v súvislosti s nealkoholovou toxikomániou v Slovenskej republike. Bratislava: Ševt, 2007. s. 15. [cit. 2021-06-12]. Dostupné na internete: https://docplayer.net/47945953-Hmotnopravne-aspekty-trestnej-cinnosti-pachanej-v-suvislosti-s-nealkoholovoutoxikomaniou-v-slovenskej-republike-judr.html.

${ }^{3}$ Jed. [cit. 2021-06-12]. Dostupné na internete: https://sk.wikipedia.org/wiki/Jed.

${ }^{4}$ ČENTÉŠS, J.: Hmotnoprávne aspekty trestnej činnosti páchanej v súvislosti s nealkoholovou toxikomániou v Slovenskej republike. Bratislava: Ševt, 2007. s. 20. [cit. 2021-06-12]. Dostupné na internete: https://docplayer.net/47945953-Hmotnopravne-aspekty-trestnej-cinnosti-pachanej-v-suvislosti-s-nealkoholovoutoxikomaniou-v-slovenskej-republike-judr.html.

${ }^{5} \S 130$ zákona č. 300/2005 Z. z. Trestný zákon v znení neskorších právnych predpisov.
} 


\section{PRÁVNE ROZPRAVY ON-SCREEN III. - Sekcia verejného práva}

online vedecká konferencia - 7. máj 2021

je nízky, resp. úplne chýba. Ďalším súvisiacim pojmom je závislost’. Táto predstavuje príznaky, ktoré vznikajú ako následok pôsobenia drog na psychiku človeka a jeho organizmus, ked’že droga najčastejšie pôsobí práve takýmto spôsobom - súčasne na duševnú aj telesnú stránku jedinca. Pri závislosti hovoríme o psychickom alebo fyzickom, prípadne i kombinovanom stave závislosti od drogy. Podl'a svetovej zdravotníckej organizácie ide o ,psychický a niekedy tiež telesný stav vyplývajúci zo vzájomného pôsobenia medzi živým organizmom a drogou, charakterizovaný zmenami správania a inými reakciami, ktoré vždy zahŕňajú nutkanie brat' drogu stále alebo pravidelne pre jej psychické účinky a niekedy tiež preto, aby sa zabránilo nepríjemnostiam vyplývajúcim z jej nepritomnosti. Tolerancia môže byt’ prítomná alebo nepritomná. Osoba môže byt' závislá od viac ako jednej drogy.“ V tejto súvislosti je možné rozlišovat' psychickú a fyzickú závislost' jednotlivých osôb. Pri psychickej závislosti ide o zmenu duševného stavu vznikajúcu podávaním drogy. Môže íst' o nutkanie ale aj o neodolatel'nú potrebu drogu užit', hoci užívatel' sám vie, že jeho konanie je nerozumné a pravdepodobne ju ani užit’ nechce. Vznik psychickej závislosti sa najčastejšie viaže práve na zážitky spájané s užitím drog. Práve psychická závislost' sa stáva rizikovou pre mladých l'udí, ktorí svoj vol’ný čas trávia prevažne v skupinách priatel’ov, s ktorými sa cítia dobre. Naopak, fyzická závislost' sa vyvíja dlhodobejšie a závisí aj od častejšieho užívania drog, v prípade, ak sa užitie drogy na určitý čas preruší, prichádzajú abstinenčné príznaky. Tieto sa začnú aktivovat’ vtedy, ked' sa hladina drog v tele začne znižovat'. Z uvedeného vyplýva, že droga má dve základné vlastnosti. Prvou je jej psychotropný efekt, ktorý je schopný modifikovat' prežívanie jednotlivcov meniac spôsob jeho videnia a prežívania sveta. Druhou vlastnost'ou je, že droga má potenciál závislosti, teda jej pravidelné a dlhodobé užívanie môže vyvolat' závislost'. Na základe toho je možné drogy, podl'a ich účinkov na psychiku, následne delit' do viacerých skupín. V súčasnosti už drogy prestávajú byt' záležitost'ou podsvetia, podnikatel’ov a kriminálnikov a čoraz viac sa dostávajú aj do stredných vrstiev spoločnosti. Na trhu neustále narastá ich množstvo a ten sa začína orientovat' predovšetkým na deti a mládež. To, okrem iného vedie aj k prudkému nárastu prvokonzumentov. Faktorov, ktoré ovplyvňujú ponuku je mnoho. Patrí sem prevažne geografické umiestnenie štátu, rozvíjajúce sa hospodárstvo s neustálym nárastom medzinárodného obchodu často s nedostatočnou kontrolou na hraniciach, rozvoj chemického a farmaceutického priemyslu, liekov a liečiv, ktoré sú potenciálnym zdrojom surovín pre výrobu drog. Ide predovšetkým o lieky obsahujúce látky akými sú napríklad efedrín a pseudoefedrín, ktorých ukončenie alebo aspoň eliminácia a st’aženie predaja 


\section{PRÁVNE ROZPRAVY ON-SCREEN III. - Sekcia verejného práva}

online vedecká konferencia - 7. máj 2021

by mohlo prípadne znížit' aj schopnost' podomovej výroby. Ďalej vel'ké množstvo domácich nelegálnych výrobcov, príliv cudzincov, ochota niektorých jedincov zapojit' sa do obchodovania hoci aj za nízke odmeny či vidina vysokého zisku spojeného s ilegálnym obchodom, bude aj nad'alej lákat' vel'ký počet osôb. Je však samozrejmé, že ide o fenomén, ktorý by neexistoval, keby po ňom nebolo dopytu. Preto, ked' hovoríme o drogovej kriminalite, je potrebné si uvedomit' aj jej odvodenú príčinu. ${ }^{6}$

S prihliadnutím na rozmanitost', dostupnost' a objemy omamných a psychotropných látok na európskej úrovni aj vzhl’adom na ich jednoduchú dostupnost’ v rámci schengenského priestoru je možné konštatovat', že drogová scéna Slovenskej republiky pozitívne reaguje na trendy vývoja či už európskej alebo svetovej drogovej scény. Pre predstavu o drogovom trhu na úrovni Európskej únie stačí poukázat' na štatistiky EMCDDA publikované v Správe o drogovej scéne v EÚ za rok 2019, kde sa uvádza, že v roku 2017 boli v rámci EÚ zobchodované drogy ako kokaín, heroín, marihuana či extáza a amfetamíny v minimálnej hodnote 30 miliárd eur. Na porovnanie, rozpočet Európskej únie na rok 2019 bol schválený vo výške 165,8 miliardy eur $^{7}$. To znamená, že nelegálne obchodovanie s omamnými a psychotropnými látkami a prekurzormi iba $\mathrm{v}$ rámci Európskej únie predstavovalo ročne minimálne $18 \%$ celého rozpočtu Európskej únie. ${ }^{8}$

V súčasnosti sa veková hranica prvých kontaktov s drogami znižuje a médiá nás pravidelne informujú o narastajúcom počte mladistvých závislých na drogách. Lahká dostupnost' drog medzi mládežou ich zaradila medzi takmer bežnú súčast' života mladej generácie, pre ktorú nie je problém nájst' a vyhl’adat' kontakty s drogovým prostredím. Drogová kriminalita spojená s det'mi a mládežou je čoraz aktuálnejšou témou. O tom, že deti sa v poslednom období častejšie stávajú obet’ami drogovej kriminality svedčí aj množstvo súdnych rozhodnutí v tejto oblasti. V tomto prípade však o det’och ako o obetiach drogovej kriminality môžeme hovorit' vo viacerých významoch. Môže íst' o deti, ktoré sa dobrovol’ne stanú konzumentmi drog a tým aj, v prenesenom význame, ich obet’ami, obet’ami drogovej

\footnotetext{
${ }^{6}$ Ministerstvo vnútra Slovenskej republiky, Prezídium policajného zboru, národná kriminálna agentúra, národná protidrogová jednotka. Správa o stave a vývoji drogovej scény na území Slovenskej republiky v roku 2017. Bratislava: 2018, s. 25. [cit. 2021-05-21]. Dostupné na internete: file://C:/Users/ondre/Downloads/Drogova\%20scena\%202017.pdf

7 Rozpočet Európskej únie na rok 2019. [cit. 2021-04-01]. Dostupné na internete: https://www.consilium.europa.eu/sk/infographics/eu-budget-2019/

${ }^{8}$ European Monitoring Centre for Drugs and Drug Addiction and Europol. EU Drug Markets Report 2019. [online]. Luxembourg: Publications Office of the European Union, 2019. [cit. 2021-05-01]. s.29. Dostupné na internete: https://www.emcdda.europa.eu/system/files/publications/12078/20192630_TD0319332ENN_PDF.pdf
} 


\section{PRÁVNE ROZPRAVY ON-SCREEN III. - Sekcia verejného práva}

online vedecká konferencia - 7. máj 2021

kriminality sa môžu stat' aj vtedy, ak ich rodičia sú na drogách závislí a svoje deti zanedbávajú či vtedy, ak pomáhajú drogovým dílerom so zobchodovaním drog. Drogová kriminalita týkajúca sa detských obetí často súvisí aj s inou trestnou činnost'ou, a to predovšetkým s majetkovou, kedy sa deti dopúšs’ajú drobných krádeží, aby si za získaný profit následne mohli obstarat' drogu, prípadne si na tento účel priamo požičajú finančnú hotovost', ktorú potom nie sú schopné vrátit', v čoho dôsledku môže dôjst' k páchaniu d’alšej trestnej činnosti, ako napríklad v prípade vydierania uvedeného nižšie, kedy sa diet’a stalo obet’ou takéhoto trestného činu.

\section{Drogová kriminalita}

Kriminalitou sa zaoberá veda o kriminalite - Kriminológia. Rovnocenná definícia kriminológie je aj veda o zločine. V podmienkach Slovenskej republiky je však na účely kriminológie pojem zločin nejasný. Z latinského prekladu slova crimen sa zločinom rozumie laicky trestný čin. Z trestnoprávneho hl'adiska je však význam tohto slova odlišný. V zmysle $\S$ 9 Trestného zákona je trestným činom v menej závažnej podobe prečin a v závažnejšej podobe zločin. Preto je nutné chápat' obe definície rovnocenne, nakol'ko by sa definícia kriminológie ako vedy o zločine mohla pre právnu obec zdat’ zavádzajúcou. Kriminológia skúma kriminalitu ako sociálno - patologický jav, ako najzávažnejšie porušenie sociálnych pravidiel správania sa. Takýmto nežiadúcim javom je napríklad alkoholizmus či drogové závislosti. ${ }^{9}$ Širším pojmom je pojem delikvencia, ktorý zahŕňa aj trestné činy spáchané osobami, ktoré nie sú trestne zodpovedné. ${ }^{10} \mathrm{~V}$ zmysle legálneho ponímania kriminality je kriminalitou trestná činnost', ktorá je sankcionovaná a vykazuje znaky trestných činov uvedených v Osobitnej časti Trestného zákona. V európskych krajinách je kriminalita tradične stotožňovaná práve s trestnou činnost'ou a teda legálne vnímanie kriminality je uprednostňované pred sociologizujúcim vnímaním. Jeho výhodou je určitost', presnost' a jednoznačnost'. ${ }^{11}$

Doterajšie poznatky z výskumov drogovej kriminality však nasvedčujú, že vo vel'kej miere ide o kriminalitu latentnú. Vysoká miera latencie sa spája predovšetkým s užívaním omamných a psychotropných látok a sofistikovaným spôsobom komunikácie. Problémom je,

\footnotetext{
${ }^{9}$ KLIMEK, L. a kol.: Kriminológia vo vnútroštátnom a medzinárodnom rozmere. 1. vydanie. Bratislava: Wolters Kluwer, 2020, s. 22.

${ }^{10}$ Tamiež, s. 9 .

${ }^{11}$ KLIMEK, L. a kol.: Kriminológia vo vnútroštátnom a medzinárodnom rozmere. 1. vydanie. Bratislava: Wolters Kluwer, 2020, s. 28.
} 


\section{PRÁVNE ROZPRAVY ON-SCREEN III. - Sekcia verejného práva}

online vedecká konferencia - 7. máj 2021

Že v uvedenej situácii zväčša chýba oznamovatel’ takejto protiprávnej činnosti, ktorý je pre iné druhy kriminality typickým. Preto tu kl'účovú úlohu zohrávajú najmä policajné zložky, ktoré samé svojou aktívnou činnost'ou musia odhal'ovat' tento druh kriminality. ${ }^{12}$

Právne vymedzenie drogových trestných činov nájdeme v Trestnom zákone v $§ 171$ až $\S$ 174. Ide o trestné činy nedovolenej výroby omamných a psychotropných látok, jedov a prekurzorov, ich držanie a obchodovanie $\mathrm{s}$ nimi ${ }^{13}$, ktoré primárne chránia život a zdravie osôb ale i celú spoločnost' pred ohrozením vyplývajúcim z nekontrolovatel'ného nakladania s omamnými a psychotropnými látkami, jedmi a prekurzormi. ${ }^{14}$ Zároveň spoločnost' chráni aj pred nekontrolovaným nakladaním s omamnými, psychotropnými látkami, jedmi a prekurzormi, ktoré ohrozujú život a zdravie, resp. záujem spoločnosti na kontrole nakladania s takýmito látkami. ${ }^{15} \mathrm{Z}$ hl’adiska objektívnej stránky stačí samotné ohrozenie života alebo zdravia. Trestnej činnosti sa teda dopustí ten, kto

1.) podl'a $\S 171$

a) neoprávnene prechováva pre vlastnú potrebu omamnú látku, psychotropnú látku, jed alebo prekurzor,

b) neoprávnene prechováva pre vlastnú potrebu omamnú látku, psychotropnú látku, jed alebo prekurzor vo väčšom rozsahu.

2.) podl'a $\S 172$ neoprávnene

a) vyrobí,

b) dovezie, vyvezie, prevezie alebo dá prepravit',

c) kúpi, predá, vymení, zadováži,

d) prechováva po akúkol'vek dobu

omamnú látku, psychotropnú látku, jed alebo prekurzor, alebo kto takú činnost' sprostredkuje.

3.) podl’a $§ 173$ sebe alebo inému zadováži alebo prechováva predmet určený na nedovolenú výrobu omamnej látky, psychotropnej látky, jedu a prekurzora.

\footnotetext{
${ }^{12}$ ČERNÍK, J. - LISOŇ, M.: Drogová kriminalita: Úvod do štúdia. Bratislava: Akadémia PZ, Bratislava, 1997, s. 34.

${ }^{13} \S \S 171-173$ zákona č. 300/2005 Z.z. Trestný zákon v znení neskorších predpisov.

${ }^{14}$ IVOR, J. - POLÁK, P. - ZÁHORA, J.: Trestné právo hmotné II. Osobitná čast'. Bratislava: Wolters Kluwer, 2016. s.81

${ }^{15}$ MENCEROVÁ, I. a kol.: Trestné právo hmotné: Osobitná čast'. 2. vydnie. Šamorín: Heuréka, 2018, s. 71.
} 


\section{PRÁVNE ROZPRAVY ON-SCREEN III. - Sekcia verejného práva}

online vedecká konferencia - 7. máj 2021

4.) podl’a $\S 174$ sa tohto trestného činu dopustí ten, kto zvádza iného na zneužívanie inej návykovej látky než alkoholu alebo ho v tom podporuje alebo kto zneužívanie takej látky inak podnecuje alebo šíri.

Trestný čin šírenia toxikománie predstavuje zvyčajne vášnivú a chorobnú túžbu po drogách. Svetová zdravotnícka organizácia vymedzuje toxikomániu ako „stav periodickej alebo chronickej intoxikácie jedinca, pričom tento stav je vyvolávaný opakovaným užitím drogy prírodnej alebo syntetickej a škodí jednotlivcovi, ako i celej spoločnosti." Toxikománia je podmienená nielen neodolatel'ným nutkaním či potrebou pokračovat' v užívaní drogy a túžbou drogu získavat' dokonca akýmkol'vek prostriedkami, ale aj psychickou závislost'ou od jej účinkov a potrebou neustáleho zvyšovania dávok. ${ }^{16} \mathrm{Z}$ hl'adiska triedenia trestných činov podl’a následku, ktorý je trestným činom spôsobený ide o ohrozujúci trestný čin. Toto ustanovenie chráni pred nebezpečným ohrozovaním návykovou látkou inou akou je alkohol.

Zvádzaním sa rozumie určitá forma návodu. Takéhoto konania sa zvyčajne dopúšt'a práve osoba, ktorá sama požíva návykovú látku. Podporovaním môže byt' napríklad aj finančný príspevok na zabezpečenie, resp. samotné sprostredkovanie takejto látky. Pod podnecovaním a šírením toxikománie možno rozumiet' predovšetkým propagovanie pozitívnych účinkov drog.

\section{Diet'a ako obet' drogovej kriminality}

Často sa o drogovej kriminalite hovorí ako o kriminalite bez obetí, čo je v skutočnosti dané špecifickým postavením konzumentov, ktorí samých seba nevnímajú ako obete alebo poškodených a čo na viac, často sa stáva, že kryjú osoby, ktoré im drogy dodávajú.

Právna úprava obetí trestných činov je v slovenskom právnom poriadku daná zákonom č. 274/2019 Z.z. o obetiach trestných činov a o zmene a doplnení niektorých zákonov, ktorým sa vykonáva transpozícia Smernice 2012/29/EÚ ${ }^{17}$ a Smernice 2004/80/ES do právneho poriadku Slovenskej republiky. Pojem obet' môžeme v najširšom zmysle chápat' ako osobu, ktorá utrpela nejaké poranenie alebo škodu. V rámci odbornej literatúry však existuje viacero chápaní tohto pojmu. V najširšom zmysle môžeme za obet' považovat' jednotlivca alebo skupinu l'udí, ktorí utrpeli akúkol’vek ujmu spôsobenú nie len trestným činom, ale napríklad aj živelnou pohromou,

\footnotetext{
${ }^{16}$ NOVOMESKÝ, F.: Drogy: História, medicína, právo. Martin: Advent Orion, 1996. s. 13.

${ }^{17}$ Smernica Európskeho parlamentu a Rady 2012/29/EÚ z 25. októbra 2012, ktorou sa stanovujú minimálne normy v oblasti práv, podpory a ochrany obetí trestných činov a ktorou sa nahrádza rámcové rozhodnutie Rady 2001/220/SVV (Ú. v. EÚ L 315/57, 14.11.2012).
} 


\section{PRÁVNE ROZPRAVY ON-SCREEN III. - Sekcia verejného práva}

online vedecká konferencia - 7. máj 2021

katastrofou, diskrimináciou či vojnou. V širšom význame sa pod pojmom obet’ rozumie osoba, prípadne organizácia, právny či morálny poriadok, ktorý je poškodený alebo zničený trestným činom. V užšom zmysle je obet'ou iba fyzická osoba, ktorá trestným činom utrpela akúkol'vek ujmi či už na živote, zdraví, majetku, cti či iných právach. ${ }^{18}$

Vo všeobecnosti môžeme povedat', že každá obet' je svojim spôsobom zranitel'ná. Avšak, niektoré z obetí sú obzvlášt' zranitel'nými, a to predovšetkým z dôvodu ich prípadnej d’alšej viktimizácie. Nakol'ko práve pri takýchto osobách existuje vysoká pravdepodobnost', že im hrozí d’alšia ujma, vyžadujú osobitné postavenie. Zranitel'nost' spočíva najmä v určitých osobnostných črtách týchto osôb, ich zdravotných t'ažkostiach či v ich samotnom správaní. Tieto faktory vytvárajú určitý stav, podmienený ich vplyvmi, ktorý možno nazvat' ako náchylnost' stat' sa obet'ou trestného činu. Preto je vel'mi dôležité vytvárat' také opatrenia, ktoré v čo najvyššej miere zamedzia pravdepodobnosti vzniku d'alších škôd. ${ }^{19}$

Obzvlášt' zranitel'ná obet' má zákonom priznaný širší rozsah pomoci, podpory a služieb, na ktoré má nárok a zároveň, $v$ trestnom konaní, má nárok nie len na špecifický postup zo strany subjektov poskytujúcich pomoc obetiam, ale aj zo strany orgánov činných v trestnom konaní.

$\mathrm{Na}$ účely zákona o obetiach trestných činov sa obzvlášs' zranitel'nou obet'ou rozumie aj diet'a. „,Diet'at'om sa rozumie osoba mladšia ako osemnást' rokov, a ak nie je vek osoby známy a existuje dôvod domnievat'sa, že je diet'at'om, považuje sa za diet’a, až kým sa nepreukáže opak".

Vychádzajúc z klasickej definície obete, podl’a ktorej sa jednotlivec stáva obet'ou vtedy, ak je objektívne narušené jeho právo a zároveň taký stav subjektívne prežíva s nevôlou alebo bolest'ou, možno práve deti považovat', z hl'adiska viktimológie, za osobitnú skupinu obetí. Avšak, práve v prípade detí nemožno s uvedenou definíciou súhlasit’ doslovne, a to z dôvodu, že môžu nastat' prípady, kedy páchatelia zmenia diet’ati stav vedomia, napríklad podaním omamných alebo psychotropných látok. Toho následkom deti nemusia pocit’ovat' ani bolest' ani nevôl'u. Dokonca, samé seba nemusia v danom momente vnímat' ako obet', ako je tomu napríklad pri násilí páchanom na det'och, kedy si deti nie sú vedomé, že sú násiliu vystavované. Z dlhodobého hl'adiska sa deti síce stávajú najčastejšie obet’ami násilnej a mravnostnej kriminality, čo na nich zanecháva nie len vnútorné psychické napätie a stres, ale aj celkový a t’ažko napravitel'ný zásah v živote, s ktorým sa len vel'mi t’ažko vyrovnávajú, avšak za

\footnotetext{
${ }^{18}$ KLIMEK, L. a kol.: Kriminológia vo vnútroštátnom a medzinárodnom rozmere. 1. vydanie. Bratislava: Wolters Kluwer, 2020, s. 322.

${ }^{19}$ ZÁHORA, J.: Zákon o obetiach trestných činov. Komentár. 1. vydanie. Bratislava: Wolters Kluwer, 2018, s. 64.
} 


\section{PRÁVNE ROZPRAVY ON-SCREEN III. - Sekcia verejného práva}

online vedecká konferencia-7. máj 2021

posledné obdobie nie je možné opomenút' ani neustále rozširujúci sa trend drogovej kriminality, ktorá, bohužial', neobchádza ani deti. Traumatizácia z trestnej činnosti sa môže prejavit' až po niekol'kých rokoch, ${ }^{20}$ či už v podobe krátkodobých dôsledkov, ktorými sú smútok, úzkost' či plač a tiež dôsledkov dlhodobých, ktoré sa môžu odrazit’ v ich štúdiu či neskoršom pracovnom živote a zároveň môžu zapríčinit' ich izoláciu od ostatných l'udí ${ }^{21}$. Preto je na mieste, aby sa rodičia s det'mi snažili mat' čo najbližší vzt'ah a udržiavali komunikáciu, ktorá im môže naznačit', že práve ich diet'a sa stalo obet'ou trestného činu. ${ }^{22}$

Vzhl'adom na nízky vek týchto osôb, ich nedostatočnú rozumovú a vôl'ovú vyspelost' v spojení s ich bezbrannost'ou voči páchatel'ovi a ich naivite, kvôli ktorej často nie sú schopné rozoznat' úmysel, sú deti považované za obzvlášs' zranitel'né obete trestnej činnosti. Základ ochrany diet'at'a jednoznačne spočíva na rodine a tiež na najbližšom sociálnom prostredí diet'at’a, v škole. Avšak, ak tieto inštitúcie zlyhajú, je úlohou štátu aby zabránil tomu, aby k páchaniu trestnej činnosti na takýchto osobách došlo. Typickým prejavom sociálnopatologického správania u detí je predovšetkým ich stále prebiehajúci vývoj či už fyzický alebo psychický, sociálna nezrelost' a náhle zmeny v ich správaní, a to najmä v období dospievania. Deti sa postupne odpútavajú od rodičov, spochybňujú ich názory a v ich spávaní prevažuje citová stránka nad rozumovou. Zväčša odmietajú prijat' to, čo im hovorí spoločnost', snažia sa vytvorit' si vlastný svet a svoje hodnoty. V snahe o samostatnost' sa však môže stat', že nastanú krízové situácie, s ktorými sa nebudú vediet' sami vyrovnat', čo môže viest' k negatívnemu sebahodnoteniu. S pocitom nízkeho sebavedomia súvisí ich náchylnost' na užitie prvej dávky drogy za účelom zvýšenia vlastnej hodnoty, prípadne vyzdvihnutia svojej osoby v očiach kamarátov. $^{23}$ Charakteristickou črtou je predovšetkým odmietanie pomoci od rodičov, pedagógov a okolia, z čoho pramení ich snaha vystupovat' ako samostatná dospelá osoba. Neuvedomujú si pri tom však svoju biologickú nezrelost' a neskúsenost'. V snahe zapáčit' sa rovesníkom, sú často schopní urobit’ čokol’vek. Takéto správanie sa pre nich stáva atraktívnym z dôvodu túžby po dobrodružstve, uznaní a úspechu. Často ich k tomu môže viest' aj nezáujem okolia a svoje konanie vnímajú ako určitý prostriedok na posilnenie vlastnej identity alebo ako prostriedok na upriamenie pozornosti či potrestanie rodičov za ich nevšímavost'. ${ }^{24}$

\footnotetext{
${ }^{20}$ Ide o tzv. ,sleeper effect“".

${ }^{21}$ ČÍRTKOVÁ, L.: Dítě jako obět’ trestného činu. In: Právo a rodina. 2005, roč. 7, č. 5, s. 16.

${ }^{22}$ HANUŠOVÁ, J.: Sexuální zneužívání dětí. Príznaky a následky. In: Právo a rodina. 2006, roč. 8, č. 5, s. 12.

${ }^{23}$ MATOUŠEK, O. - MATOUŠKOVÁ, A.: Mládež a delikvence. Praha : Portál s. r. o., 2011, s. 56.

${ }^{24}$ KOUDELKOVÁ, A.: Psychologické otázky delikvence. Praha : Victoria Publishing, 1995, s. 99.
} 


\section{PRÁVNE ROZPRAVY ON-SCREEN III. - Sekcia verejného práva}

online vedecká konferencia - 7. máj 2021

Obet’ami drogovej kriminality sa deti môžu stat' či už ako konzumenti alebo ako osoby využívané na obchod s drogami. ${ }^{25}$ Náchylnost' detí stat' sa obet'ami drogovej kriminality potvrdzuje nespočetné množstvo súdnych rozhodnutí, z ktorých priamo, ale často aj nepriamo vyplýva, že sa stali obet’ami drogovej kriminality. Či už ide o rozhodovania vo veciach týkajúcich sa priamo drogových trestných činov, alebo aj rozhodnutia v iných veciach, v ktorých najmä počas dokazovania vyšli tieto skutočnosti najavo.

Drogy sa, bohužial', v dnešnej dobe dostávajú k čoraz mladším det'om. Túto skutočnost' potvrdzuje aj prípad maloletého chlapca, ktorý bol umiestnený v detskom domove a neskôr $\mathrm{v}$ reedukačnom centre a vykazoval dlhodobé problémové správanie. U chlapca bola opakovane potvrdená prítomnost' marihuany $\mathrm{v}$ jeho organizme. $\mathrm{V}$ čase jeho umiestnenia $\mathrm{v}$ detskom domove, detský domov musel opakovane riešit’ návrhy na zvýšenú výchovnú starostlivost', ktoré aj napriek neúnavnej snahe o zlepšenie, neviedli k jeho náprave. Jeden z týchto návrhov, kvôli nezvládnutel'nému správaniu maloletého, spísali aj ostatné deti z detského domova, ktoré s ním boli umiestnené v skupine. Maloletý nerešpektoval pokyny a nariadenia vychovávatel'ov, fajčil na izbe či na balkóne aj napriek tomu, že mu to bolo výslovne zakázané. Vyskytovali sa u neho agresívne fyzické a často aj vulgárne prejavy voči ostatným det'om a k celému okoliu. Maloletý svojím správaním ohrozoval predovšetkým seba, svoje zdravie a svojím impulzívnym a agresívnym správaním aj ostatné deti a vychovávatel'ov. Následne bol podrobený psychologickému vyšetreniu, kde psychologička, okrem iného, konštatovala, že vzhl’adom k jeho návykom na konzumáciu drog je nutná jeho pravidelná kontrola a v prípade, ak by nebol nezvládol otvorený systém $\mathrm{v}$ rámci detského domova, bolo by nevyhnutné hl'adat' také zariadenie, kde by sa zamedzilo kontaktu s návykovou látkou a ak by sa dopustil vážneho priestupku, bude potrebné navrhnút' umiestnenie v reedukačnom centre. Nakol'ko jeho správanie nebolo zvládnutel'né bežným spôsobom v prostredí detského domova, kde boli vyčerpané všetky možnosti, okresný súd nariadil detskému domovu povinnost' odovzdat' maloletého do starostlivosti reedukačného centra. Zo správy reedukačného centra vyplýva, že správanie maloletého sa zlepšilo. Maloletý sa vyhýbal otvoreným konfliktom, nedopúšt’al sa žiadnych závažnejších priestupkov, v rovesníckej skupine mal priatel’ské vzt’ahy, dospelých formálne rešpektoval, avšak prejavila sa u neho letargia a k plneniu školských povinností bolo potrebné ho viest', občas aj s vyvíjaním mierneho tlaku. Ako konštatovala psychologička,

${ }^{25}$ ČERNÍK, J. - LISOŇ, M.: Drogová kriminalita: Úvod do štúdia. Bratislava: Akadémia PZ, Bratislava, 1997, s. 34. 


\section{PRÁVNE ROZPRAVY ON-SCREEN III. - Sekcia verejného práva}

online vedecká konferencia - 7. máj 2021

dôvodom takéhoto správania sa maloletého boli práve málo stimulujúce rodinné pomery, konflikty medzi rodičmi a nevyriešené bytové možnosti, ktoré sa prejavili najmä v stagnácii jeho výkonov v škole. ${ }^{26} 27$

V d'alšom prípade, ktorého predmetom konania bol síce zločin vydierania vyšlo najavo, že poškodený maloletý dlhodobo užíval drogy. Obžalovaný mal od maloletého poškodeného žiadat' finančné prostriedky pod hrozbou násilia. Poškodený vypovedal, že obžalovanému dlžil len 50 EUR za „trávu“. Z listinných dôkazov sa potvrdila nie len komunikácia ohl'adne vyššej finančnej hotovosti, ale aj to, že maloletý poškodený bol dovtedy užívatel’om drog. Túto skutočnost' zistil Okresný súd Trenčín z výpovedí, ked’ sa maloletý poškodený snažil utajit' svoje drogové problémy a aj finančné podlžnosti voči ostatným osobám. Už v pôvodnom rozsudku súd poukazoval na jeho zníženú dôveryhodnost', nakol'ko dlhy, ktoré maloletý spôsobil boli zapríčinené pôžičkou na drogy. ${ }^{28} \mathrm{~V}$ uvedenom prípade sa síce konanie pred súdom neviedlo priamo za drogovú trestnú činnost', avšak z prípadu je zrejmé, že zločin vydierania, za ktorý bol obžalovaný odsúdený, bol dôsledkom konania maloletého, ktorý bol obžalovanému dlžný peniaze, ktoré potreboval na nákup drog.

\section{Nedovolená výroba omamných a psychotropných látok, jedov alebo prekurzorov, ich držanie a obchodovanie s nimi}

V uvedenom prípade súd schválil dohodu o vine a treste uzatvorenú medzi prokurátorkou Krajskej prokuratúry Nitra a obvineným mladistvým. Mladistvý bol uznaný vinným za to, že zadovažoval, prechovával a následne predával, dával bezplatne alebo aj vymieňal za iné veci drogu - marihuanu konzumentom, ktorými bolo najmenej šest' osôb, z toho išlo aj o chránenú osobu - diet’a a osobu mladšiu ako pätnást' rokov. Dopustil sa teda obzvlášt' závažného zločinu nedovolenej výroby omamných a psychotropných látok, jedov alebo prekurzorov, ich držania a obchodovania s nimi podl'a $\S 172$ odsek 1 písmeno c), písmeno d), odsek 2 písmeno c), písmeno d), odsek 3 písmeno b) Trestného zákona s poukazom na $§ 138$ písmeno b), písmeno j) Trestného zákona a s poukazom na $§ 139$ odsek 1 písmeno a) Trestného zákona. Za to mu súd uložil „podl'a § 172 odsek 3 Trestného zákona, zistiac pol’ahčujúce okolnosti podl'a § 36 písmeno j), písmeno l), písmeno n) Trestného zákona a nezistiac

\footnotetext{
${ }^{26}$ Rozsudok Okresného súdu Skalica, sp. zn.: 8P/156/2017 zo dňa: 07.02.2018.

${ }^{27}$ Pozri aj Uznesenie Okresného súdu Partizánske, sp. zn.: 6P/52/2020 zo dňa 31.08.2020.

${ }^{28}$ Rozsudok Okresného súdu Trenčín, sp. zn.: 2T/114/2017 zo dňa: 03.07.2018.
} 


\section{PRÁVNE ROZPRAVY ON-SCREEN III. - Sekcia verejného práva}

online vedecká konferencia - 7. máj 2021

prit’ažujúcu okolnost' podl'a § 37 Trestného zákona s použitím § 117 odsek 1 Trestného zákona, § 38 odsek 2, odsek 3 Trestného zákona, § 51 odsek 1 Trestného zákona a § 39 odsek 4 Trestného zákona trest odñatia slobody vo výmere 2 (dva) roky. “ Podl'a $§ 51$ odsek 1 Trestného zákona súd výkon uloženého trestu podmienečne odložil a zároveň uložil probačný dohl’ad nad správaním obvineného v skúšobnej dobe. Podl’a $§ 51$ odsek 2 Trestného zákona v spojení s $§$ 119 odsek 1 Trestného zákona Trestného zákona súd ustanovil skúšobnú dobu na 3 (tri) roky. Podl’a $§ 51$ odsek 4 písmeno g) Trestného zákona súd uložil povinnost’ spočívajúcu v príkaze podrobit' sa $\mathrm{v}$ súčinnosti $\mathrm{s}$ probačným a mediačným úradníkom alebo iným odborníkom programu sociálneho výcviku alebo inému výchovnému programu. Zároveň mu bol uložený aj trest prepadnutia veci, a to mobilného telefónu a finančnej hotovosti uloženej na účte banky. Bolo mu uložené aj ochranné opatrenie - zhabanie veci, a to elektronickej váhy ${ }^{29}$.

Ďalší prípad sa týka obžalovanej, ktorá sa taktiež dopustila obzvlášt' závažného zločinu nedovolenej výroby omamných a psychotropných látok, jedov alebo prekurzorov, ich držania a obchodovania s nimi podl'a $§ 172$ odsek 1 písm. c/, písm. d/, odsek 2 písm. c/, písm. d/ Trestného zákona s poukazom na ustanovenie $§ 138$ písm. j/ Trestného zákona a $§ 139$ odsek 1 písm.a/ Trestného zákona s tým, že zadovážila a prechovávala vo svojom byte rôzne druhy omamných a psychotropných látok, najmä však metamfetamín, ktoré následne distribuovala medzi bežných užívatel'ov drog, a to aj maloletej osobe. V uvedenej veci rozhodoval Krajský súd o odvolaní obžalovanej. Ten mal za to, že v uvedenom prípade nebolo rozhodujúce či obžalovaná poznala vek osoby, ale to, že spôsob predaja drogy jednoznačne nasvedčoval jej l'ahostajný vzt'ah k následku, a teda aj k veku týchto osôb a nakol'ko si ich vek nijakým spôsobom neoverovala, mala byt' uzrozumená s tým, že sa môže jednat' aj o osobu mladšiu ako 18 rokov. Okresný súd obžalovanú odsúdil k nepodmienečnému trestu odňatia slobody vo výmere 10 rokov, uložil jej ochranný dohl'ad na 2 roky, trest prepadnutia veci - finančnej hotovosti a injekčnej striekačky. Odvolací súd nezistil žiadne pochybenie, ktoré by malo mat' vplyv na objasnenie veci a uplatnenie práva na obhajobu a na základe dokazovania vykonaného súdom prvého stupňa nemal krajský súd žiadne pochybnosti o tom, že sa obžalovaná dopustila skutku. Krajský súd potvrdil správnost' všetkých výrokov a odvolanie obžalovanej ako nedôvodné zamietol. ${ }^{30}$

\footnotetext{
${ }^{29}$ Rozhodnutie o návrhu na schválenie dohody o vine a treste, Okresný súd Nitra, sp. zn.: 5Tk/1/2018 zo dňa: 19.07.2018.

${ }^{30}$ Uznesenie Krajského súdu Trnava, sp. zn.: 3To/127/2019 zo dňa: 24.09.2019.
} 


\section{PRÁVNE ROZPRAVY ON-SCREEN III. - Sekcia verejného práva}

online vedecká konferencia - 7. máj 2021

Okresný súd Banská Bystrica rozhodol, že obžalovaný sa dopustil obzvlášt’ závažného zločinu Nedovolenej výroby omamných a psychotropných látok, jedov alebo prekurzorov, ich držania a obchodovania s nimi podl’a $§ 172$ ods. 1 písm. c), písm. d), ods. 2 písm. d) Trestného zákona s poukazom na $§ 139$ ods. 1 písm. c) Trestného zákona. Zároveň bol oslobodený spod obžaloby pre zločin Sexuálneho zneužívania podl’a § 201 ods. 1, ktorého sa mal dopustit’ na tej istej osobe - jeho dcére, nakol'ko nebolo preukázané, že sa skutok stal. Pod vplyvom alkoholu držal svoju dcéru rukou zozadu za krk a za ruku a nútil ju, aby spolu s ním vyfajčila dva kusy cigariet zo sušiny rastlín rodu Cannabis, pričom mal vedomost', že v tom čase maloletá nedovíšila fyzický vek 15 rokov, teda neoprávnene zadovážil a prechovával po akúkol'vek dobu omamnú látku a čin spáchal na chránenej osobe a voči osobe mladšej ako pätnást' rokov, čím spáchal obzvlášt’ závažný zločin nedovolenej výroby omamných a psychotropných látok, jedov alebo prekurzorov, ich držania a obchodovania s nimi podl’a $§ 172$ ods. 1 písm. c), písm. d), ods. 2 písm. d), ods. 3 písm. b) Trestného zákona s poukazom na $§ 139$ ods. 1 písm. c) Trestného zákona. Za to bol podl’a $\S 172$ ods. 3, § 38 ods. 2, ods. 3 a 8, § 36 písm. j), § 39 ods. 1, ods. 3 písm. b), § 46 Trestného zákona odsúdený na trest odňatia slobody vo výmere 10 (desat') rokov nepodmienečne. ${ }^{31} 32$

\section{Záver}

V závere je možné konštatovat', že z trestnoprávneho hl'adiska stále rezonujú diskusie o trestnoprávnej zodpovednosti či už za držanie alebo konzumáciu drog. Aj napriek tomu, že štatistiky neodhalia celkovú kriminalitu a sprihliadnutím na kriminalitu latentnú sa objektívnost' štatistických ukazovatel'ov stáva skôr relatívnou, dokážu nám vytvorit' aspoň obraz o registrovanej trestnej činnosti. Podiel drogovej kriminality ${ }^{33}$ za posledné tri roky nepresiahol 3\% ${ }^{34}$ vo vzt’ahu k celkovej kriminalite. Na prvý pohl'ad sa to javí ako nízky podiel,

\footnotetext{
${ }^{31}$ Rozsudok Okresného súdu Banská Bystrica, sp. zn.: 1Tk/1/2020.

${ }^{32}$ Pozri aj Rozsudok Okresného súdu Nové Mesto nad Váhom, sp. zn.: 1T/11/2020 zo dňa 13.07.2020, Rozsudok Okresného súdu Trenčín, sp. zn.: 3Tk/3/2019 zo dňa 08.09.2020, Rozsudok Krajského súdu Trenčín, sp. zn.: 23To/108/2020 zo dňa 30.11.2020.

${ }^{33} \mathrm{~V}$ štatistikách kriminality však nájdeme iba údaje o trestných činoch, ktoré boli odhalené, a preto je nevyhnutné pamätat' aj na latentnú kriminalitu, nakol'ko práve drogová kriminalita sa vyznačuje vysokou mierou latencie. Na to, aby sme dospeli k objektívnym výsledkom by teda bolo potrebné k celkovej drogovej kriminalite pripočítat' aj kriminalitu latentnú.

34 Štatistika spracovaná autorkou z jednotlivých Štatistík kriminality v Slovenskej republike za roky 2017 - 2020 zverejnených na web stránke Ministerstva vnútra Slovenskej republiky. Údaje predstavujú podiel drogovej kriminality k celkovej kriminalite. V roku 2018 sa celkovej kriminality dopustilo 61392 páchatel'ov, z čoho 1573 páchatel'ov sa dopustilo drogovej kriminality, teda približne $2,56 \%$. Zaujímavost’ou vyplývajúcou zo štatistiky je
} 


\section{PRÁVNE ROZPRAVY ON-SCREEN III. - Sekcia verejného práva}

online vedecká konferencia-7. máj 2021

treba však povedat', že rozhodne nejde o zanedbatel'né čísla. Je možné predpokladat', že tento trend bude pokračovat' aj v nasledujúcom období, nakol'ko ho ovplyvňuje aj vývin drogových scén a záujmy konzumentov v susedných krajinách, najmä v Českej republike. Tým, že sa neustále rozširuje ponuka nových psychoaktívnych látok, zvyšuje sa aj záujem o ne medzi konzumentmi. Drogová kriminalita je závažný celosvetový problém. Užívanie drog sa v poslednom období stalo výsadou predovšetkým mladej generácie, ktorá už v relatívne nízkom veku začína s experimentovaním, ktoré sa postupne pretaví do pravidelného užívania neuvedomujúc si riziká závislosti na týchto látkach. Avšak, s užívaním drog u detí ide ruka v ruke aj páchanie inej trestnej činnosti. Drogová kriminalita detí však vychádza predovšetkým z ich závislosti na drogách, čo znamená, že drogová kriminalita aj iné trestné činy sú páchané v dôsledku drogovej závislosti. Príčin, pre ktoré mladí l’udia začínajú s drogami je mnoho. Ide predovšetkým o negatívne pôsobiace rodinné a sociálne prostredie, zlá či nesprávna výchova, rozvod rodičov, vplyv rovesníkov či anonymita väčších miest. V poslednom období sa problémovým stáva aj obchod s drogami, ktorý sa zameriava práve na mládež, predstavujúcu najl’ahšiu korist'. Drogová problematika a s ňou spojená trestná činnost' však nie je len otázkou represie. Zásadnú úlohu v tomto prípade zohráva prevencia, ktorá je dôležitá najmä v prípade tejto, najviac ohrozenej, skupiny. Preventívne opatrenia, by mali pôsobit’ takým spôsobom, aby k trestnému stíhaniu mládeže dochádzalo v čo najnižšej miere. Ide však o zložitý proces, ktorý si vyžaduje adekvátne nie len sociálne a pracovné, ale aj vzdelávacie programy pomoci. Avšak, prevencia by primárne mala vychádzat' zo samotného rodinného prostredia. Priaznivé podmienky v oblasti prevencie by mali byt' taktiež vytvorené na úrovni škôl, v kultúrnej či sociálnej oblasti tak, aby mládež mala priestor na efektívne využívanie vol'ného času, zdravý vývoj a skvalitňovanie životných podmienok a celkovú socializáciu. Škola by mala vytvárat' v det'och pozitívny prístup k zdravému a zdraviu neohrozujúcemu životnému štýlu a prehlbovat' negatívny vzt'ah k agresívnemu správaniu a rizikám spojených s užívaním

\footnotetext{
skutočnost', že pod vplyvom drog bolo spáchaných 159 skutkov, z toho napríklad 3 vraždy či 6 dopravných nehôd. Ohrozenia pod vplyvom návykovej látky sa dopustilo 56 páchatel'ov pod vplyvom drog, pričom pod vplyvom alkoholu to bolo až 4512 páchatel'ov. Páchatelia pod vplyvom drog sa opät' najčastejšie dopúšt’ali násilnej a majetkovej kriminality. Zo štatistiky za rok 2019 vyplýva, že zistenej drogovej kriminality sa dopustilo približne $2,92 \%$ z celkového počtu páchatel'ov, konkrétne 1723 páchatel'ov z celkového počtu 58829 páchatel'ov. Pod vplyvom drog konalo 206 páchatel'ov, pričom v porovnaní s predošlými dvoma rokmi sa takýto páchatelia častejšie dopúšt’ali majetkovej, než násilnej kriminality. Štatistika vyhotovená za rok 2020 obsahuje iba údaje zozbierané od januára do novembra. Z uvedeného vyplýva, že celkový počet zistených páchatel’ov bol 54244 , drogovej kriminality sa dopustilo 1513 páchatel'ov, čo predstavuje 2,78 \% podiel na celkovej kriminalite. Z uvedeného je možné konštatovat', že páchanie kriminality má klesajúcu tendenciu a percentuálny podiel drogovej kriminality na celkovej kriminalite za posledné 3 roky neprekročil $3 \%$.
} 


\section{PRÁVNE ROZPRAVY ON-SCREEN III. - Sekcia verejného práva}

online vedecká konferencia - 7. máj 2021

návykových látok, a tým zároveň zvyšovat' ich povedomie nie len o zdravotných a sociálnych, ale aj právnych dôsledkoch takého správania sa. V tomto prípade je však vel'mi dôležité, aby mal pedagóg odborné znalosti a profesionálnu zdatnost' na to, aby dokázal pozitívne vplývat' na osobnostný rozvoj žiaka. Prevencia by sa mala stat' povinnou a neoddelitel'nou súčast'ou nášho každodenného života. Mala by vychádzat' z vnútorného presvedčenia každého jednotlivca. Ciel'om prevencie by sa však nemala stat' iba absencia sociálno-patologických javov. Mala by vychádzat' zo sociálne priaznivého správania a hodnôt v spoločnosti. Prevencia kriminality by sa mala stat' prirodzenou súčast'ou rodiny, školskej politiky a programov miest a obcí, ktoré by zabezpečili adekvátne a optimálne podmienky na realizáciu prevencie v praxi.

Sankcie ustanovené našou platnou právnou úpravou sú vo všeobecnosti jedny z najprísnejších v rámci Európskej únie. Bolo by vhodné, predovšetkým u detí a mládeže, aby tieto tresty boli nižšie, resp. plnili skôr výchovný účel a namiesto zameriavania sa na samotný následok vo forme uloženia trestnej sankcie, riešili príčiny takéhoto správania sa a prípadnú liečbu. Rovnako tak stojí za zváženie aj podporenie tejto diskusie v oblasti priestupkového konania. Informácie o trendoch a miere užívania drog v spoločnosti by nepochybne mali byt' základom pre formovanie racionálnej a primeranej drogovej politiky a zároveň tak by mali byt' smerodajné pri hodnotení jej efektivity. Mladí l’udia majú v tejto oblasti nízku úroveň právneho vedomia a ich povedomie sa často zvýši až vtedy, ked’ sú trestne stíhaní. Je vel'mi dôležité, aby dnešná mládež mala dostatočné vedomosti o tom, čo je drogová kriminalita nielen z pohl’adu zdravia, ale najmä z hl'adiska prípadného trestného stíhania, nakol'ko nie je vhodné začínat' svoju kariéru práve trestnou činnost'ou.

\section{ZOZNAM BIBLIOGRAFICKÝCH ODKAZOV}

ČERNÍK, J. - LISOŇ, M.: Drogová kriminalita: Úvod do štúdia. Bratislava: Akadémia PZ, Bratislava, 1997. 103 s. ISBN 80-8054-031-4.

IVOR, J. - POLÁK, P. - ZÁHORA, J.: Trestné právo hmotné II. Osobitná čast'. Bratislava: Wolters Kluwer, 2016. 648 s. ISBN 978-80-8168-586-6.

KLIMEK, L. a kol.: Kriminológia vo vnútroštátnom a medzinárodnom rozmere. 1. vydanie. Bratislava: Wolters Kluwer, 2020. 780 s. ISBN 978-80-571-0251-9. 


\section{PRÁVNE ROZPRAVY ON-SCREEN III. - Sekcia verejného práva}

online vedecká konferencia - 7. máj 2021

KOUDELKOVÁ, A.: Psychologické otázky delikvence. Praha : Victoria Publishing, 1995, 114 s. ISBN 978-8071870227.

MATOUŠEK, O. - MATOUŠKOVÁ, A.: Mládež a delikvence. Praha : Portál s. r. o., 2011. 344 s. ISBN 978-80-7367-825-8.

MENCEROVÁ, I. a kol.: Trestné právo hmotné: Osobitná čast’. 2. vydnie. Šamorín: Heuréka, 2018. 448 s. ISBN 978-80-8173-057-3.

NOVOMESKÝ, F: Drogy: História, medicína, právo. Martin: Advent Orion, 1996. 120 s. ISBN 80-88719-49-6.

ZÁHORA, J.: Zákon o obetiach trestných činov. Komentár. 1. vydanie. Bratislava: Wolters Kluwer, 2018. 414 s. ISBN 978-80-8168-850-8.

ČÍRTKOVÁ, L.: Dítě jako obět’ trestného činu. In: Právo a rodina. 2005, roč. 7, č. 5. 12-16 s. ISSN 1212-866X.

HANUŠOVÁ, J.: Sexuální zneužívání dětí. Príznaky a následky. In: Právo a rodina. 2006, roč. 8, č. 5. 12-16 s. ISSN 1212-866X.

Smernica Európskeho parlamentu a Rady 2012/29/EÚ z 25. Októbra 2012, ktorou sa stanovujú minimálne normy v oblasti práv, podpory a ochrany obetí trestných činov a ktorou sa nahrádza rámcové rozhodnutie Rady 2001/220/SVV (Ú. v. EÚ L 315/57, 14.11.2012).

Zákon č. 301/2005 Z.z. Trestný poriadok v znení neskorších právnych predpisov.

Zákon č. 225/1988 Z.z. o odškodňovaní osôb poškodených násilnými trestnými činmi.

Zákon č. 2015/2006 Z.z. o odškodňovaní osôb poškodených násilnými trestnými činmi.

Zákon č. 274/2017 Z.z. o obetiach trestných činov a o zmene a doplnení niektorých zákonov.

Rozhodnutie o návrhu na schválenie dohody o vine a treste, Okresný súd Nitra, sp. zn.: $5 T k / 1 / 2018$ zo dňa 19.07.2018.

Rozsudok Okresného súdu Skalica, sp. zn.: 8P/156/2017 zo dňa 07.02.2018.

Rozsudok Okresného súdu Trenčín, sp. zn.: 2T/114/2017 zo dňa 03.07.2018.

Uznesenie Krajského súdu Trnava, sp. zn.: 3To/127/2019 zo dňa 24.09.2019.

Rozsudok Okresného súdu Banská Bystrica, sp. zn.: 1Tk/1/2020 zo dňa 26.05.2020.

Rozsudok Okresného súdu Nové Mesto nad Váhom, sp. zn.: 1T/11/2020 zo dňa 13.07.2020

Uznesenie Okresného súdu Partizánske, sp. zn.: 6P/52/2020 zo dňa 31.08.2020. 


\section{PRÁVNE ROZPRAVY ON-SCREEN III. - Sekcia verejného práva}

online vedecká konferencia - 7. máj 2021

Rozsudok Okresného súdu Trenčín, sp. zn.: 3Tk/3/2019 zo dňa 08.09.2020

Rozsudok Krajského súdu Trenčín, sp. zn.: 23To/108/2020 zo dňa 30.11.2020.

ČENTÉŠ, J. Hmotnoprávne aspekty trestnej činnosti páchanej v súvislosti s nealkoholovou toxikomániou v Slovenskej republike. Bratislava: Ševt, 2007. s. 15. [cit. 2021-06-12]. Dostupné na internete: https://docplayer.net/47945953-Hmotnopravne-aspekty-trestnej-cinnostipachanej-v-suvislosti-s-nealkoholovou-toxikomaniou-v-slovenskej-republike-judr.html.

European Monitoring Centre for Drugs and Drug Addiction and Europol. EU Drug Markets Report 2019. [online]. Luxembourg: Publications Office of the European Union, 2019. [cit. 2021-05-01]. S.29. Dostupné na internete: https://www.emcdda.europa.eu/system/files/publications/12078/20192630_TD0319332ENN_ PDF.pdf

Rozpočet Európskej únie na rok 2019. [cit. 2021-04-01]. Dostupné na internete: https://www.consilium.europa.eu/sk/infographics/eu-budget-2019/

Správa o stave a vývoji drogovej scény - Ministerstvo vnútra Slovenskej republiky, Prezídium policajného zboru, národná kriminálna agentúra, národná protidrogová jednotka. Správa o stave a vývoji drogovej scény na území Slovenskej republiky v roku 2017. Bratislava: 2018, s. 25. [cit. 2021-06-11].

Dostupné na internete:

file://C:/Users/ondre/Downloads/Drogova\%20scena\%202017.pdf

Štatistika kriminality v Slovenskej republike za rok 2017. Štatistika podl'a druhu kriminality za obdobie od 01.01.2017 do 31.12.2017. [cit. 2021-06-11]. Dostupné na internete: https://www.minv.sk/?Statistika_kriminality_v_SR_za_rok_2017

Štatistika kriminality v Slovenskej republike za rok 2018. Štatistika podl'a druhu kriminality za obdobie od 01.01.2018 do 31.12.2018. [cit. 2021-06-11]. Dostupné na internete: https://www.minv.sk/?statistika_kriminality_2018

Štatistika kriminality v Slovenskej republike za rok 2019. Štatistika podl'a druhu kriminality za obdobie od 01.01.2019 do 31.12.2019. [cit. 2021-06-11]. Dostupné na internete: https://www.minv.sk/?statistika kriminality v slovenskej republike za rok 2019 xml Štatistika kriminality v Slovenskej republike za rok 2020. Štatistika podl'a druhu kriminality za obdobie od 01.01.2020 do 30.11.2020. [cit. 2021-06-11]. Dostupné na internete: https://www.minv.sk/?statistika_kriminality_v_slovenskej_republike_za_rok_2020_xml 
PRÁVNE ROZPRAVY ON-SCREEN III. - Sekcia verejného práva

online vedecká konferencia - 7. máj 2021

\section{(c) (1)}

Obsah článku podlieha licencii Creative Commons Attribution 4.0 International Licence CC BY (Silvia Ondrejková). 